\title{
PERBEDAAN SELF EFFICACY PADA IBU MENYUSUI POST PARTUM NORMAL DAN POST SECTIO CAESAREA DI RSUD SEKARWANGI KABUPATEN SUKABUMI
}

\author{
Susilawati ${ }^{1}$, Sofiea Febryaningsih ${ }^{2}$ \\ ${ }^{1}$ Dosen Sekolah Tinggi Ilmu Kesehatan Sukabumi \\ ${ }^{2}$ Sekolah Tinggi Ilmu Kesehatan Sukabumi \\ Email : susi0580@yahoo.com
}

\begin{abstract}
Abstrak
Target cakupan ASI Ekslusif bayi masih rendah dari 80\% target cakupan ASI Ekslusif nasional. Self efficacy pada Ibu menyusui merupakan rasa percaya diri atau keyakinan yang dimiliki oleh ibu untuk menyusui dan menjadi predictor dalam pemberian ASI Ekslusif pada bayinya, baik pada Ibu post partum normal maupun Post Sectio Caesarea. Tujuan penelitian untuk mengetahui Perbedaan Self efficacy pada ibu menyusui post partum normal dengan Post Sectio Caesare. Jenis penelitian menggunakan study komparasi dengan sampel 70 responden, dan pengambilan sampel dengan quota sampling. Kuesioner menggunakan Breastfeeding Self Efficacy (BSE). Analisis data menggunakan uji independent sampel T-test. Hasil penelitian menunjukan pada lbu menyusui Post Partum Normal diperoleh mean sebesar 60,48, sedangkan pada Ibu menyusui post partum sectio caesare diperoleh mean sebesar 46,80. Terdapat perbedaan Self Efficacy pada Ibu menyusui post partum normal dengan post sectio caesare dengan nilai $p$-value 0,000 . Hasil penelitian dapat menjadi acuan dalam meningkatkan penyuluhan pada ibu menyusui tentang pentingnya pemberian ASI Ekslusif pada bayi usia 0-6 bulan.
\end{abstract}

Keywords: Self efficacy menyusui, ASI Ekslusif.

ABSTRACT

The target for exclusive breastfeeding for infants is still lower than $80 \%$ of the national exclusive breastfeeding coverage target. Breastfeeding self-efficacy is the confident or belief possessed by mothers to breastfeed and be a predictor in exclusive breastfeeding for their babies, both in normal postpartum mothers and Post Sectio Caesarea. The purpose of this study was to determine the differences in self-efficacy in normal postpartum breastfeeding mothers with post sectio caesarea. This type of research uses a comparative study with a sample of 70 respondents and sampling with quota sampling. The questionnaire uses Breastfeeding Self Efficacy (BSE). Data analysis used an independent sample t-test. The results showed that the postpartum normal breastfeeding mothers obtained a mean of 60.48 , while the postpartum cesarean breastfeeding mothers obtained a mean of 46.80. There is a difference in selfefficacy in normal postpartum breastfeeding mothers with post sectio caesarea with a p-value of 0,000. The results of the study can be a reference in increasing counseling to nursing mothers about the importance of exclusive breastfeeding in infants aged 0-6 months.

Keywords: Breastfeeding self efficacy, ASI Ekslusif. 


\section{PENDAHULUAN}

ASI merupakan nutrisi terbaik yang telah terbukti memberi manfaat kesehatan besar bagi ibu,bayi dan masyarakat (Prior, et all, 2012). Menyusui dapat mengurangi kejadian dan tingkat keparahan penyakit pada bayi seperti: penyakit otitis media, infeksi gastrointestinal, enterokolitis, infeksi saluran pernafasan bagian bawah, sindrom kematian bayi mendadak, obesitas dan diabetes. Hal ini disebabkan karena ASI memiliki manfaat sebagai zat anti infeksi yang mengandung Immunoglobulin A (Ig.A), Laktoferin, enzim lysozim, sel darah putih dan faktor bifidus (Riordan, 2005).

Jumlah sel darah putih yang terkandung dalam ASI (Air Susu Ibu) pada dua minggu pertama berkisar lebih dari 4000 selpermil yang terdiri dari tiga macam yaitu Bronchus Asociated Lympocyte Tissue (BALT) antibo di pernafasan, Gut Asociated Lympocyte Tissue (GALT) antibodi saluran pernafasan, dan Mammary Asociated Lympocyte Tissue (MALT) antibodi jaringan payudara ibu.

Faktor bifidus dalam ASI yaitu sejenis karbohidrat yang mengandung nitrogen menunjang pertumbuhan bakteri Lactobacillus bifidus. Bakteri ini menjaga keasaman flora bayi dan berguna untuk menghambat pertumbuhan bakteri merugikan (Kementerian Pemberdayaan Perempuan dan Perlindungan Anak Republik Indonesia, 2010).

Menyusui juga memiliki manfaat besar bagi ibu diantaranya dapat menurunkan angka kejadian kanker ovarium dan kanker payudara. Ibu-ibu yang menyusui selama 3 tahun akan terhindar dari risiko kanker payudara, hal ini disebabkan karena didalam ASI terdapat zat Human-Alpha-lactalbumin Made-Lethal to Tumorcells atau dikenal dengan HAMLET yang dapat membunuh 40 jenis sel kanker dengan keuntungan tidak membunuh sel-sel sehat. Zat ini terdiri dari protein dan asam lemak yang ditemukan secara alami didalam ASI (Roesli,2008).
Menyusui bagi ibu juga dapat mencegah terjadinya diabetes tipe 2 , hal ini disebabkan karena perubahan metabolisme ibu menyusui membantu menstabilkan kadar gula darah dan meningkatkan sensitivitas tubuh terhadap hormon insulin.

Ibu yang menyusui bayinya terus menerus selama paling sedikit satu tahun dapat menurunkan kadar gula darah. Selain itu ibu yang menyusui bayinya memiliki kecenderungan memilih gaya hidup sehat dibandingkan dengan ibuyangtidak menyusui. Umumnya ibu-ibu yang menyusui lebih selektif memilih makanan sehat dan bergizi agar kandungan ASI yang diberikan pada bayi juga memiliki zat gizi yang tinggi. Gaya hidup semacam ini dapa mendorong metabolisme tubuh untuk mengurangi risiko terjadinya diabetes tipe2 (Ip, Chung, Raman, Trikalinos \& Lau, 2009; Yulfitrawasi, 2011).

Bukti-bukti mengenai besarnya manfaat pemberian ASI eksklusif telah banyak diketahui secara luas namun dilaporkan bahwa tingkat pemberian ASI eksklusif masih sangat rendah diberbagai penjuru negara (American Academy of Pediatrics, Section on Breastfeeding 2012).

Meningkatnya persalinan melalui bedah caesar secara signifikan merupakan salahsatu faktor pemicu rendahnya pemberian ASI eksklusif diseluruh dunia. Bedah sesar secara luas dapat memengaruhi proses menyusui yang buruk dan berdampak terhadap keberhasilan menyusui. Beberapa hasil studi melaporkan bahwa tingkat menyusui pada ibu dengan bedah sesar lebih rendah bila dibandingkan dengan ibu yang melahirkan secara normal (Prior et al 2012; Perez-Rioz et al., 2007).

Pemberian ASI setelah melahirkan bisa menjadi proses yang tidak mudah bagi seorang ibu, dikarenakan ibu pada masa menyusui merupakan 
masa yang paling sensitif baik dalam kehidupan ibu secara fisik atau emosional. Ibu pasca melahirkan mungkin akan mengalami kendala pada waktu menyusui yang mengalami kegelisahan, kecemasan dan ketidaknyamanan secara psikologis dengan kelahiran anak, sering atau banyak juga ibu yang kurang pengetahuan tentang faktor yang dapat mempengaruhi kelancaran produksi ASI, dampak psikologis terdapat kelancaran produksi ASI, ibu merasa pesimistis mengenai jumlah yang dihasilkan.

Merurut Abdilah (2004) terdapat beberapa faktor yang mempengaruhi ibu dalam pemberian ASI ekslusif diantaranya psikologis dan pengetahuan ibu. Takut kehilangan daya tarik sebagai seorang wanita. Adanya anggapan para ibu bahwa menyusui akan merusak penampilan. Tekanan batin membuat ibu mengurangi frekuensi dan lama menyusui bayinya, bahkan berhenti menyusui. Tingkat pendidikan dan akses ibu terhadap media masa juga mempengaruhi pengambilan keputusan, dimana semakin tinggi pendidikan semakin besar peluang untuk memberikan ASI (menyusui). Sebaliknya akses terhadap media berpengaruh negatif terhada pemberian ASI, dimana semakin tinggi akses ibu pada media semakin tinggi peluang untuk tidak memberikan ASI.

Masalah seperti ini sering dijumpai pada ibu masa postpartum, kekecewaan ini bisa terjadi karena adanya masa transisi menjadi orang tua, kecemasan saat postpartum yang dirasakan dapat menjadi salah satu faktor memengaruhi kelancaran produksi ASI, kecemasan itu sendiri mulai timbul ketika individu menghadapi pengalaman-pengalaman baru dimulainya dari kehamilan, proses melahirkan dan setelah melahirkan (Stuart \& Sundeen,1993 dikutip dalam pratiwi,2010).

Hasil temuan lain yang dilaporkan pada ibu dengan bedah sesar adalah adanya penurunan minat beberapa ibu untuk menyusui (Smith, 2010). Rasa percaya diri dan keinginan ibu untuk menyusui sangat dipengaruhi oleh keyakinan ibu untuk menyusui bayinya atau breastfeeding self efficacy (BSE).

Breastfeeding Self Efficacy (BSE) yakni keyakinan seorang ibu pada kemampuannya untuk menyusui atau memberikan ASI pada bayinya (Dennis \& Foux, 1999). Menurut Dennis (1999) BSE merupakan suatu komponen yang dapat memprediksi seorang ibu untuk memilih memulai menyusui atau tidak, berapa banyak usaha ibu untuk tetap menyusui bayinya, apakah ibu memiliki pola pikir yang dapat meningkatkan menyusui serta bagaimana ibu dapat mengatasi hambatan selama menyusui secara emosional. Rendahnya rasa percaya diri terutama pada ibu paska bedah sesar menyebabkan persepsi ibu tentang kurangnya ASI dan berisiko untuk segera berhenti menyusui (Lauwers dan Swisher, 2011; Handayani, Kosnin, Jiar \& Solikhah, 2013).

Keyakinan ibu menyusui baru-baru ini menjadi topik permasalahan yang telah disorot oleh berbagai peneliti dalam menilai kondisi psikologis ibu untuk meningkatkan menyusui (Meedya, Fahy, \& Kable, 2010). Faktor-faktor yang dapat mempengaruhi self efficacy seseorang antara lain budaya, gender, sifat dari tugas yang dihadapi, insentif eksternal, status atau peran individu dalam lingkungan serta informasi tentang kemampuan diri yang belum dilakukan yang dapat meningkatkan motivasi (Pradini, 2015).

Breastfeeding self efficacy merupakan rasa percaya diri yang dimiliki oleh ibu dalam hal menyusui yang dapat menjadi predictor apakah ibu akan memutuskan untuk menyusui, sebesar apa upaya yang akan dilakukan untuk menyusui, apakah mempunyai pola pikir membangun atau merusak dan bagaimana cara merespons berbagai masalah dan kesulitan selama menyusui (Tores et all., 2003). 
Breastfeeding self efficacy berpengaruh pada respons individu berupa pola pikir,reaksi emosional, usaha dan kegigihan serta keputusan yang akan diambil (Denis, 2010). Denis menjelaskan keputusan yang dimaksud adalah inisiasi menyusui, menyusui secara efektif dan keberlanjutan menyusui (ASI eksklusif). Self efficacy yang rendah dalam hal menyusui dapat menyebabkan persepsi dan motivasi yang negatif (Bandura, 1994; Denis, 2010).

Berbagai penelitian menunjukkan bahwa breastfeeding self efficacy merupakan faktor penting yang berhubungan dengan inisiasi, durasi dan keeksklusifan menyusui (McQueen, 2011).

Penelitian yang dilakukan oleh Handayani et all (2010) membuktikan bahwa ada hubungan yang erat antara dukungan sosial, pengetahuan, sikap dan self efficacy dengan perilaku menyusui. Penelitian lain mendapatkan hasil bahwa ibu yang mempunyai breastfeeding self efficacy yang tinggi cenderung untuk tetap menyusui selama 4 bulan (Blythetal,2002). Ibu dengan breast feeding selfefficacy yang rendah terbukti cenderung menggunakan teknik alternatif untuk menyusui bayinya ketika menghadapi masalah selama menyusui (Keemer,2011). Berbagai hasil penelitian tersebut membuka wacana barubah breast feeding self efficacy diduga berhubungan erat dengan keberhasilan praktik menyusui.

Dennis (2010) menerangkan bahwa terdapat 4 sumber yang memengaruhi breastfeeding selfefficacy yaitu: 1) pengalaman menyusui bayi secara langsung; 2) pengalaman tidak langsung yang diperoleh melalui pengamatan atau cerita orang lain yang berhasil menyusui; 3) persuasi verbal dari teman, keluarga atau petugas kesehatan tentang laktasi; dan 4) respons fisiologisberupa ada tidaknya stress, keletihan atau kecemasan yang menyertai. Intervensi dalam paket dukungan menyusui yang diberikan pada kelompok perlakuan disusun berdasarkan 4 sumber tersebut, sehingga peningkatan breastfeeding self efficacy yang ditunjukkan oleh responden dalam kelompok perlakuan membuktikan bahwa teori yang dikemukakan oleh Dennis adalah benar.

Ibu yang telah memiliki pengalaman menyusui secara langsung cenderung lebih percaya diri untuk terus menyusui, apalagi memang sejak awal mayoritas responden memiliki breastfeeding self efficacy yang cukup tinggi sehingga membuat ibu lebih gigih untuk dapat terus menyusui. Pengalaman tidak langsung tentang menyusui diperoleh responden pada kelompok perlakuan melalui video menyusui yang diberikan oleh peneliti. Hal ini dapat memberi pengetahuandan keyakinan ibu dalam memberikan ASI pada bayi dikaitkan secara positif dapat meningkatkan durasi menyusui pada berbagai budaya dan kelompok usia (Dennis, 1999; Alus, Tokat, Okumus, \& Dennis, 2010).

Self Eficacy yang baik akan mengarahkan ibu pada kondisi mental yang stabil,sehingga mampu menerima arahan. Ibu hamil dan bersalin yangtelah mendapatkan persiapan menghadapi persalinan dalam bentuk latihan birth ball dan psikologis, akan mendapatkan proses pembelajaran dan pengalaman, sehingga dapat lebih mempersiapkan diri menjalani kontraksi, untuk selanjutnya dapat beradaptasi terhadap nyeri dan ketidaknyaman selama proses persalinan. efikasi diri yang dimiliki individu rendah, dapat menyebabkan hambatan dalam proses adapatasinya meskipun individut ersebut memiliki potensi yang besar. Self eficacy yang tinggi menyebabkan munculnya (self regulated learning yang tinggi (Perrin,2013).

Tetapi ibu yang melahirkan secara normal tidak tertutup kemungkinan memiliki self eficacy yang buruk dalam inisiasi menyusui dini. Menurut penelitian yang dilakukan Aisya (2017), seorang 
ibu yang baru saja melahirkan akan melewati beberapa fase adaptasi dimana ibu dinyatakan memiliki adaptasi yang baik jika sampai pada fase letting go. Jika ibu gagal sampai pada fase letting go, maka ibu akan mengalami stres post partum. Stres pada ibu post partum berpengaruh terhadap keyakinan (self efficacy) sebab salah satu faktor yang mempengaruhi efikasi diri adalah tingkat status emosional. Ibu post partum dengan tingkat stres tinggi akan memiliki efikasi diri yang rendah. Tujuan penelitian ini adalah untuk mengetahui hubungan tingkat stres pada ibu post partum terhadap keyakinan.

Data yang penulis dapatkan di RSUD Sekarwangi Kabupaten Sukabumi pada tahun 2017 jumlah ibu yang melakukan inisasi menyusui dini yaitu sebanyak 23 orang di ruangan kelas II dan 64 orang diruangan kelas Illdari total 620 orang yang melahirkan secara spontan dan 927 orang ibu yang melahirkan melalui pembedahan section caesarea, untuk lebih jelasnya dapat dilihat pada tabel 1 :

Tabel 1

Distribusi Frekuensi Ibu Melahirkan Di Ruang Raden Dewi Sartika RSUD Sekarwangi Pada Tahun 2017

\begin{tabular}{|c|c|c|c|c|c|c|}
\hline \multirow{2}{*}{$\begin{array}{c}\text { N } \\
\text { o }\end{array}$} & \multirow{2}{*}{$\begin{array}{c}\text { Ibu } \\
\text { Melahirkan }\end{array}$} & \multicolumn{2}{|c|}{$\begin{array}{c}\text { Kelas Rawat } \\
\text { inap }\end{array}$} & \multirow{2}{*}{ IMD } & Jmlh & $\%$ \\
\cline { 3 - 5 } & II & III & & & \\
\hline 1 & $\begin{array}{c}\text { Melahirkan } \\
\text { Sesar }\end{array}$ & 182 & 790 & 139 & 972 & 14 \\
\hline 2 & $\begin{array}{c}\text { Melahirkan } \\
\text { Spontan }\end{array}$ & 156 & 464 & 430 & 620 & 69 \\
\hline & Jumlah & 338 & 1254 & 569 & 1592 & 83 \\
\hline
\end{tabular}

Berdasarkan Tabel 1 Diketahui bahwa ibu yang melahirkan secara bedah sesar pada tahun 2017 sebanyak 927 orang ibu hanya sebanyak 139 orang ibu yang melakukan inisasi menyusui dini atau hanya $14 \%$ ibu yang melakukan inisiasi menyusui dini. Ibu yang melahirkan secara spontan pada tahun 2017 di RSUD Sekarwangi yaitu sebanyak 620 orang ibu dan yang melakukan inisasi menyusui dini yaitu sebanyak 430 orang ibu atau $69 \%$ ibu yang melahirkan spontan melakukan inisasi menyusui dini, dari data tersebut dapat disimpulkan bahwa lebih banyak ibu yang melahirkan spontan melakukan inisiasi menyusui dini dibandingkan ibu yang melahirkan secara sectio caesarea.

Pemerintah Sukabumi mengimplementasikan Undang-Undang Nomor 36 Tahun 2009 tentang Kesehatan yang ditindaklanjuti dengan Peraturan Pemerintah Nomor 33 Tahun 2012 tentang Pemberian Air Susu Ibu Eksklusif, Sukabumi telah memiliki Peraturan Daerah Nomor 2 Tahun 2016 tentang Pemberian Air Susu Ibu (ASI) Ekslusif.Dalam Pasal 128 Undang-Undang Nomor 36 Tahun 2009 tentang Kesehatan menyatakan bahwa setiap bayi berhak mendapatkan air susu ibu eksklusif sejak dilahirkan selama 6 (enam) bulan, kecuali atas indikasi medis. Selama pemberian air susu ibu, pihak keluarga, pemerintah, pemerintah daerah, dan masyarakat harus mendukung ibu bayi secara penuh dengan penyediaan waktu dan fasilitas khusus dengan penyediaan fasilitas khusus diadakan di tempat kerja dan tempat sarana umum (Perda Sukabumi, 2017).

Berdasarkan Studi pendahuluan yang dilakukan penulis di ruang Raden Dewi Sartika RSUD Sekarwangi Kabupaten Sukabumi melalui wawancara terhadap 5 orang ibu yang melahirkan spontan dan 5 orang ibu yang melahirkan secara bedah sesar, didapatkan hasil bahwa ibu yang melahirkan secara sesar sebagian besar mengatakan memiliki rasa kekawatiran yang lebih untuk menyusui dini pada bayinya karena luka sayat bekas oprasi masih terasa nyeri dan ada perasaan tidak nyaman untuk memberikan ASI tetapi untuk ibu yang melahirkan secara spontan memiliki keinginan untuk memberikan ASI-nya sebagian besar mengatakan bahwa merasa puas dan bersyukur bisa merasakan rasanya melahirkan seorang bayi secara spontan, sehingga rasa ingin menjadi seorang ibu yang utuh dengan cara memberikan ASI kepada anaknya. 


\section{METODE PENELITIAN}

Penelitian ini menggunakan metode penelitian Study Komparasi. Populasi dan sampel 70 orang. Pengambilan sampel menggunakan Quota Sampling. Menggunakan Kuesioner Breastfeeding Self Efficacy (BSE). Analisis data menggunakan Uji Independent Sampel T-Test.

Hasil penelitian menunjukan pada Ibu menyusui Post Partum Normal diperoleh mean sebesar 60,48. Pada Ibu menyusui Post Partum Caesare diperoleh mean sebesar 46,80. Terdapat perbedaan Self Efficacy Pada Ibu Menyusui Post Partum Normal dengan Post partum ectio caesare dengan nilai $p$-value 0,000 .

\section{HASIL PENELITIAN}

\section{A. Analisis Univariat Variabel Self Efficacy Pada Ibu Menyusui Post Partum Normal dan Post Caesarea}

Analisis Univariat Variabel dalam penelitian ini meliputi gambaran Self efficacy pada ibu menyusui post partum normal dan Post partum sectio caesare adalah sebagai berikut:

\section{Table 2}

Gambaran Self Efficacy Pada Ibu Menyusui Post Partum Normal dan Post Caesarea

\begin{tabular}{|l|c|c|c|}
\hline \multicolumn{1}{|c|}{ Self Efficacy } & $\mathrm{n}$ & Mean & SD \\
\hline $\begin{array}{l}\text { Ibu menyusui Post Partum } \\
\text { Normal }\end{array}$ & 35 & 60,48 & 6,49 \\
\hline $\begin{array}{l}\text { Ibu menyusui Post Partum } \\
\text { Caesarea }\end{array}$ & 35 & 46,80 & 6,95 \\
\hline
\end{tabular}

Berdasarkan tabel 2 menunjukkan bahwa pada kelompok lbu menyusui Post Partum Normal diperoleh nilai rata-rata Self efficacy yang didapatkan dari 35 responden adalah sebesar 60,48 dengan nilai simpangan baku 6,49. Sedangkan pada kelompok lbu menyusui Post Partum Caesare diperoleh nilai rata-rata Self efficacy yang didapatkan dari 35 responden adalah sebesar 46,80 dengan nilai simpangan baku 6,95.

\section{B. Analisis Bivariat Perbedaan Self Efficacy Pada Ibu Menyusui Post Partum Normal dengan Post Caesare}

Hasil uji perbedaan Self Efficacy Pada Ibu Menyusui Post Partum Normal dengan Post partum section csaesare selengkapnya dapat dilihat pada tabel 3 berikut ini :

Tabel 3.

Uji Hipotesis Perbedaan Self Efficacy Pada Ibu Menyusui Post Partum Normal dengan Post Caesarea

\begin{tabular}{|l|c|c|c|c|}
\hline \multicolumn{1}{|c|}{ Self Efficacy } & N & Mean & t & $\begin{array}{c}\text { p- } \\
\text { value }\end{array}$ \\
\hline $\begin{array}{l}\text { Ibu menyusui Post } \\
\text { Partum Normal }\end{array}$ & 35 & 60,48 & & \\
\cline { 1 - 1 } $\begin{array}{l}\text { Ibu menyusui Post } \\
\text { Partum Caesarea }\end{array}$ & 35 & 46,80 & 8,509 & 0,000 \\
\hline
\end{tabular}

Berdasarkan tabel 3 menunjukkan nilai $p$-value uji independen sampel sebesar 0,000 maka $\mathrm{p}$ value $<0,05$, sehingga dapat dikatakan terdapat perbedaan Self Efficacy Pada Ibu Menyusui Post Partum Normal dengan Post Caesare. Hal tersebut dibuktikan dengan kedua kelompok mengalami perbedaan mean.

\section{PEMBAHASAN}

\section{A. Gambaran Self Efficacy Pada Ibu Menyusui Postpartum Normal di RSUD Sekarwangi Kabupaten Sukabumi}

Hasil penelitian menunjukkan bahwa pada kelompok Ibu menyusui Post Partum Normal diperoleh nilai rata-rata Self efficacy yang didapatkan dari 35 responden adalah sebesar 60,48 dengan nilai simpangan baku 6,49, artinya bahwa self efficacy ibu dalam menyusui tinggi.

Breastfeeding self efficacy merupakan rasa percaya diri yang dimiliki oleh ibu dalam hal menyusui yang dapat menjadi predictor apakah ibu akan memutuskan untuk menyusui, sebesar apa upaya yang akan dilakukan untuk menyusui, apakah mempunyai pola pikir membangun atau merusak dan bagaimana cara merespons berbagai masalah dan kesulitan selama menyusui (Tores et all., 2003).

Self efficacy mempengaruhi bagaimana seseorang berpikir, merasa, memotivasi diri sendiri dan bertindak. Self efficacy mendorong proses kontrol diri untuk mempertahankan perilaku. Self efficacy yang tinggi ibu menyusui diperlukan supaya mereka memiliki keyakinan 
dan keberhasilan dalam melakukan penatalaksanaan secara mandiri (Misnadiarly, 2006) dalam Asrikan (2016).

Keberhasilan self efficacy individu satu dari lainnya berbeda-beda. Terdapat faktor yang memengaruhi keyakinan diri individu salah satunya usia. Berdasarkan hasil penelitian menunjukkan bahwa pada kelompok ibu yang melahirkan normal sebagian besar usia responden berada pada rentang 20-35 tahun yaitu sebesar $88,6 \%$ atau sebanyak 31 responden, sedangkan sebagian kecil usia responden berada pada rentang > 35 Tahun, yaitu sebesar $11,4 \%$ atau sebanyak 4 responden.

Menurut Monk (2002) dalam Kamtono (2015) menyatakan bahwa usia dapat memengaruhi keyakinan seseorang. Usia 20 - 35 tahun adalah usia produktif untuk seorang ibu mengandung, dalam rentang usia ini ibu berada dalam periode dewasa matang dimana bisa memilih tindakan sesuai dengan hal yang seharusnya. Ketika seseorang berada dalam usia matang, ibu akan lebih yakin menyusui karena masih produktif untuk memberikan ASI yang terbaik untuk anaknya. Selain itu, pada usia ini seorang ibu secara fisik berada pada usia dewasa muda dimana pada fase ini ibu dapat berpikir secara rasional mana yang terbaik untuk anaknya ketika sudah punya anak dan fase dimana ibu mengambil keputusan dengan segala pertimbangan dan memandang dari berbagai sudut. Pada usia ini pula, seorang ibu berada pada kondisi psikologis matang untuk hamil dan mempunyai anak, sehingga tidak ada kecendrungan breastfeeding self efficacy ibu buruk. Maka tidak heran self eficacy ibu menyusui pada kelompok ibu dengan melahirkan normal memiliki niali mean tinggi.

Faktor lain yang dapat mempengaruhi breastfeeding self efficacy pada ibu menyusui, salah satunya adalah sumber informasi tentang menyusui. Kelompok ibu yang melahirkan normal seluruhnya mendapatkan informasi tentang menyusui berasal dari petugas kesehatan yaitu sebesar 100 $\%$ atau sebanyak 35 responden.

Dennis (2010) menerangkan bahwa terdapat bebarapa sumber yang memengaruhi breastfeeding self efficacy salah satunya oleh petugas kesehatan tentang laktasi. Pernyataan tersebut didukung dengan penelitian Dewi (2014) yang menyatakan bahwa salah satu faktor yang memengaruhi breastfeeding self efficacy adalah sumber informasi. Ada hubungan sumber informasi dengan keyakinan ibu menyusui, sumber informasi yang didapat dari petugas kesehatan membuat ibu semakin yakin, dan sebaliknya sumber informasi dari non petugas kesehatan membuat keyakinan ibu menyusui rendah.

\section{B. Gambaran Self Efficacy Pada Ibu Menyusui Post Sectio Caesare di RSUD Sekarwangi Kabupaten Sukabumi}

Hasil penelitian menunjukkan bahwa pada kelompok Ibu menyusui Post partum section caesare diperoleh nilai rata-rata Self efficacy yang didapatkan dari 35 responden adalah sebesar 46,80 dengan nilai simpangan baku 6,95 , artinya tingkat self efficacy ibu berada dalam kategori rendah.

Menurut Bandura, self efficacy merupakan keyakinan individu terhadap kemampuan dirinya dalam mengatur dan melakukan tugas-tugas tertentu yang dibutuhkan untuk mendapatkan hasil sesuai harapan (Ngurah \& Sukmayanti, 2014).

Menurut Bandura (dalam Jess Feist \& Feist, 2010) self efficacy dapat ditumbuhkan dan dipelajari melalui empat hal, yang pertama adalah Pengalaman menguasai sesuatu (mastery experience) keyakinan akan timbul ketika ibu menyusui memiliki keberhasilan dalam melakukan menyusui. Kedua adalah 
pengalaman orang lain (vicarious experience) keyakinan dapat meningkat ketika ibu menyusui melihat ibu menyusui yang lain dapat melakukan menyusui dengan baik. Ketiga adalah persuasi verbal (verbal persuation) pemberian motivasi yang dianggap memiliki pengaruh besar seperti dari keluarga, teman, dokter dan perawat. Keempat yaitu respon fisiologis (physiological responses) ibu menyusui akan terlihat stress dan tegang ketika tidak mampu melakukan menyusui dengan baik.

Pada kelompok ini, ditemukan bahwa nilai ratarata nilai self efficacy lebih rendah dibandingkan dengan kelompok ibu menyusui post partum normal. Menurut Dewi (2015) ibu yang melakukan persalinan dengan operasi (sesar) akan terjadi kecendrungan untuk mengeluh sakit dengan luka operasinya dan membutuhkan bantuan untuk melakukan kegiatan sehari-hari setelah dilakukan operasi. Sehingga dimungkinkan bahwa ibu yang melakukan persalinan dengan operasi sectio caesar memiliki keraguan untuk memberikan ASI secara eksklusif dengan kata lain adanya penurunan keyakinan untuk menyusui.

Faktor lain yang mendukung hasil penelitian pada kelompok sesar adalah pengalaman menyusui. Menurut Greenberg I \& Baron Hambawany (2007) mengatakan bahwa terdapat faktor yang mempengaruhi self efficacy yaitu pengalaman langsung. Berdasakan tabel 4.5 menunjukkan bahwa pada kelompok ibu yang melahirkan sesar sebagian besar melahirkan anak ke-1 yaitu sebesar 40,0\% atau sebanyak 14 responden, dengan ini dimungkinkan tidak adanya pengalaman menyusui anak. Sehingga tidak heran nilai rata-rata self efficacy ibu menyusui post partum sesar lebih rendah dibandingkan dengan nilai post partum normal.

Pengalaman langsung merupakan hasil dari pengalaman mengerjakan suatu tugas dimasa lalu (sudah pernah melakukan tugas yang sama di masa lalu). Individu yang telah mendapatkan pengalaman sebelumnya sudah dapat menyesuaikan diri dengan keadaan dalam menyusui bayi. Sehingga ibu yang tidak mempunyai pengalaman menyusui anak sebelumnya akan memiliki keraguan dalam menyusui anak ketika mempunyai seorang anak. Lowe (2010) menyebutkan bahwa ibu yang pernah tidak melahirkan sebelumnya memiliki efikasi diri yang lebih rendah dibandingkan mereka yang pernah melahirkan sebelumnya.

\section{Perbedaan Self Efficacy Pada Ibu Menyusui Post partum Normal Dengan Post Caesarea Di RSUD Sekarwangi Kabupaten Sukabumi}

Berdasarkan tabel 4.9 menunjukkan nilai pvalue uji independen sampel sebesar 0,000 maka p-value < 0,05, sehingga dapat dikatakan terdapat perbedaan Self Efficacy Pada Ibu Menyusui Post Partum Normal dengan Post partum sectio caesare. Hal tersebut dibuktikan dengan kedua kelompok mengalami perbedaan mean.

Menurut Leung (2013) menyatakan bahwa terdapat perbedaan self efficacy pada ibu yang menjalani persalinan normal dan sesar. Menurut Larkin, Begley, dan Devane (2009) perempuan yang telah berhasil dalam menjalani proses persalinan secara normal memiliki dampak meningkatnya harga diri dan merasakan hal itu sebagai suatu prestasi, dan ini akan berdampak pada keyakinan diri ibu untuk dapat menyusui.

Sedangkan persalinan yang menyakitkan seperti dengan operasi memiliki dampak psikologis yang menyebabkan kecemasan, depresi dan stres sehingga dapat mengganggu ikatan ibu dengan bayinya dan mengakibatkan efek psikologis jangka panjang bagi ibu maupun keluarganya. Perasaan senang pada ibu saat persalinannya akan berdampak pada perasaan bahagia dengan kehadiran bayinya dan akan berdampak pada kemudahan dalam menyesuaikan diri dan memulai peran menjadi ibu, perasaan ini di dapat dari persalinan normal. Sebaliknya, traumatic 
persalinan dapat mempengaruh kemampuan ibu dalam mengasuh dan memberikan Air Susu Ibu (ASI) serta mengakibatkan buruknya ikatan ibu dan bayinya (Simkin, 1992).

Rendahnya Self Eficacy pada ibu melahirkan pasca sesar di kaitkan dengan keadaan ibu baru memulihkan diri sebelum mampu untuk menggendong dan menyusui bayinya. Ketidak nyamanan, nyeri dan kelelahan merupakan kondisi psikis setelah persalinan sesio sesaria. Produksi ASI sangat dipengaruhi oleh kondisi psikis tersebut sehingga ibu akhirnya tidak berhasil menyusui dengan baik (Keyper,2009).

Hasil penelitian ini sesuai dengan penelitian yang dilakukan Larkin, Begley, dan Devane (2009) yang menunjukan bahwa adanya perbadaan keyakinan pada ibu dengan melahirkan secara normal dan sesar. Pada ibu yang melahirkan secara normal, akan lebih memiliki keyakinan lebih tinggi dibandingkan melahirkan secara sesar.

Banyak faktor yang dapat menyebabkan terjadinya perbedaan Self Eficacy pada ibu melahirkan pasca sesar dan normal. Menurut Thaib et all dalam Abdullah et all (2009) menyatakan bahwa tingkat pengetahuan, pendidikan, status kerja ibu, dan jumlah anak dalam keluarga berpengaruh positif pada Self Eficacy pada ibu dalam pemberian ASI. Selain itu faktor ekstrenal lainnya yang dapat mempengaruhi adalah dukungan keluarga, dukungan yang paling berperan dalam keberhasilan ibu menyusui adalah peran dukungan suami. Hal ini karena suami merupakan orang terdekat baik ibu dan memberikan motivasi kepada ibu untuk memberikan ASI secara eksklusif (Friedman,2008).

\section{KESI MPULAN}

Berdasarkan hasil penelitian dan pembahasan mengenai perbedaan Self Efficacy Pada Ibu Menyusui Post Partum Normal dengan Post Caesare di RSUD Sekarwangi Kabupaten Sukabumi adalah sebagai berikut :
1. Gambaran Self Efficacy Pada Ibu Menyusui Postpartum Normal di RSUD Sekarwangi Kabupaten Sukabumi didapatkan hasil nilai ratarata Self efficacy adalah sebesar 60,48 dengan nilai simpangan baku 6,49 artinya self efficacy ibu menyusui tinggi.

2. Gambaran Self Efficacy Pada Ibu Menyusui Post Caesare di RSUD Sekarwangi Kabupaten Sukabumi didapatkan hasil nilai rata-rata Self efficacy adalah sebesar 46,80 dengan nilai simpangan baku 6,95 artinya self efficacy ibu menyusui rendah.

3. Terdapat perbedaan Self Efficacy pada Ibu menyusui Post Partum Normal dengan Post Caesare di RSUD Sekarwangi Kabupaten Sukabumi.

\section{SARAN}

Hasil penelitian ini diharapkan dapat dijadikan sebagai acuan bagi petugas kesehatan yang ada di Rumah Sakit terutama perawat untuk meningkatkan Self Efficacy pada Ibu menyusui dengan memberikan penyuluhan tentang pentingnya ASI, cara memberikan ASI pada ibu sesudah melahirkan baik normal maupun sesar. Metode penyuluhan bias dengan menggunakan metode ceramah ataupun dengan media seperti booklet, brosur, poster atau leaflet untuk ibu dengan melahirkan secara normal, akan tetapi untuk ibu dengan melahirkan secara sesar dapat di lakukan role play posisi dan tekhnik menyusui pada Ibu post partum SC, sehingga meningkatkan Self Efficacy pada Ibu menyusui dengan melahirkan normal dan sesar.

\section{DAFTAR PUSTAKA}

Aghdas, Karimi., Talat, Khadizvzadeh, Sepideh, \& Bagheri. Effect of immediate and continuous mother-infant skin to skin contact on breastfeeding self-efficacy of primiparous 
women: A randomised control trial. Woman and Birth, 312. No. Of Pages 4.

Arikunto, S. 2010.Prosedur penelitian suatu pendekatan praktik. Jakarta : Rineka Cipta,.

American Academy of Pediatrics, Section on Breastfeeding.(2012). Breastfeeding and the use of human milk. Pediatrics, 129, e827e841.

Bandura, A 1994, Emory university, dilihat 21 Februari 2012, http://www.des.emody. edu/mfp/Bandura1994EHB.pdf

Bandura, A. 1997, 'Self-efficacy: toward a univying theory of behavioral change', Psichologycal Review, vol 84, no.2, hal. 191215

Blyth, R, Creedy, DK, Dennis, C-L, Moyle, W, Pratt, J \& Vries, SMD 2002. 'effect of maternal confidence on breastfeeding duration: an application of breastfeeding self-efficacy theory', birth: Issues in Prenatal Care, vol 29, no. 4, hal. 278-284.

Budiarto, Eko. 2002.Biostatistika untuk Kedokteran dan Kesehatan Masyarakat. Jakarta: EGC,

Dennis, C. L.,\& Faux, S.(1999). Development and psychometric testing of the breasfeeding self-efficacy scale. Res Nurs Health, 22, 399409.

Dennis, CL 2010, Breastfeeding Self Efficacy, dilihat 2 Maret 2012, <http:// www.cindyleedennis.ca/research/1breastfeeding/_breastfeeding-selfefficacy/>.

Handayani, L., Kosnin. A. Md., Jiar, Y. K., \& Solikhah. (2013). Translation and validation of breastfeeding self-efficacy scale-short form (BSES-SF) into Indonesian: A Pilot Studi. Kesmas, ISSN: 1978-0575.

Hidayat, A.Aziz Alimul. 2012. Metode Penelitian Keperawatan \& Tekhnik Analisis Data.Jakarta : Salemba Medika

Ip, S., Chung, M., Raman, G., Trikalinos, T. A., \& Lau, J. (2009). A summary of the agency for healthcare research and quality's evidence report on breastfeeding in developed countries. Breastfeeding Medicine, 4, S17S30. doi:10.1089/bfm.2009.0050.

Kementerian Pemberdayaan Perempuan dan Perlindungan Anak Republik Indonesia. (2010). Pedoman peningakatan penerapan 10 langkah menuju keberhasilan menyusui yang responsif gender bagi pusat dan daerah. Tersedia pada http://aimiasi.org/wp-content/ uploads/2010/08/17permenegpp-3-2010. pdf. Diakses tanggal 14 Maret 2018.

Lauwers, J., \& Swisher, A. (2011). Counseling the Nursing Mother. A Lactation Consultant's Guide, (5 $5^{\text {th }}$ Ed.). Jones and Barlett Publishers, ISBN 978-0-7637-8652- 4, Sudbury, USA.

Nurbaeti, I., \& Lestari. K.B. (2013). Efektivitas comprehensive breastfeeding education terhadap keberhasilan Air Susu Ibu (ASI) pada periode postpartum. Jurnal Keperawatan Padjajaran, 1(2), 27-36. ISSN: 2338-5324.

Nursalam.2011.Konsep dan Penerapan Metodologi Penelitian IImu Keperawatan: Pedoman Skripsi, Tesis dan Instrumen Penelitian Keperawatan. Jakarta : Salemba Medika.

Notoatmodjo, Soekidjo.2010.Metodologi Penelitian Kesehatan.Jakarta : Rineka Cipta.

McQueen, KA, Dennis, CL, Stremler, R, Norman,CD 2011. 'A pilot randomized controlled trial of a breastfeeding self efficacy intervention with primiparous mothers', JOGNN, vol 40, hal. 35-46.

Prior, Emily., Santhakumaram, Shalini., Gale, Cris., Philipps, L.H., Modi, Neena.,\& Hyde, M.J. (2012). Breastfeeding after cesarean delivery: A systematic review and metaanalysis of world literaure. American Society for Nutrition, 95, 1113-35.

Laporan ibu Melahirkan, Rekam Medik RSUD Sekarwangi Kabupaten Sukabumi.2017.

Rahayuwati, L., Ermiati, \& Trisyani, M. (2016). Proses evaluasi: Standar, efektifitas, efisiensi dan keberlangsungan pelayanan keperawatan maternitas. Jurnal Keperawatan Padjajaran, 4(2), 127-138. ISSN: 23385324.

Riordan, J. 2005. Breastfeeding and human lactation, $3^{\text {rd }}$ edition, Jones and Barlett Publishers, Canada.

Roesli, U. (2008). Mitos menyusui. Makalah dalam Seminar Telaah Mutakhir tentang ASI. Bali: FAOPS-Perinasia.

Smith, L.J. (2010). Impact of birth practices on breastfeeding $\left(2^{\text {nd }}\right.$ Ed.), Jones and Barlett Publishers, ISBN 978-0-7637-63749,Sudbury, USA 
Sugiyono. 2008.Metode penelitian pendidikan : Bandung : Alfabeta.

Torres, MM, Torres, RRD, Rodríguez, AMP \& Dennis, C-L 2003. 'Translation and validation of the breastfeeding self- efficacy scale into spanish: Data From a puerto rican population', Journal of Human Lactation, vol. 19, no. 1, hal. 35-42. 